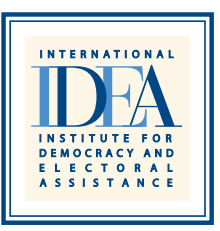

Utrecht University

\title{
The Party Abroad and its Role for National Party Politics
}

International IDEA Discussion Paper 1/2019

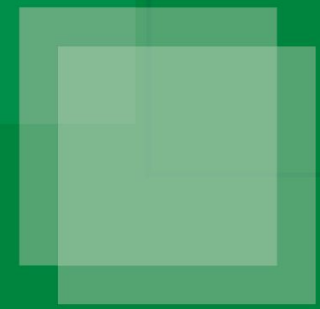




\section{The Party Abroad and its Role for National Party Politics}

International IDEA Discussion Paper 1/2019

Ekaterina R. Rashkova and Sam van der Staak 
(C) 2019 International Institute for Democracy and Electoral Assistance

This paper is independent of specific national or political interests. Views expressed in this paper do not necessarily represent the views of International IDEA, its Board or its Council members.

References to the names of countries and regions in this publication do not represent the official position of International IDEA with regard to the legal status or policy of the entities mentioned.

\section{(어요 $(0)$}

The electronic version of this publication is available under a Creative Commons Attribute-NonCommercial-ShareAlike 3.0 (CC BY-NC-SA 3.0) licence. You are free to copy, distribute and transmit the publication as well as to remix and adapt it, provided it is only for non-commercial purposes, that you appropriately attribute the publication, and that you distribute it under an identical licence. For more information on this licence visit the Creative Commons website: 〈http://creativecommons.org/licenses/by-nc-sa/3.0/〉.

International IDEA

Strömsborg

SE-103 34 Stockholm

Sweden

Telephone: +4686983700

Email: info@idea.int

Website: 〈http://www.idea.int〉

Design and layout: International IDEA

Created with Booktype: 〈https://www.booktype.pro〉 


\section{Contents}

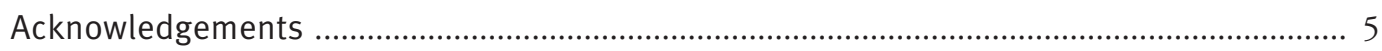

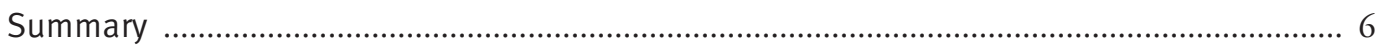

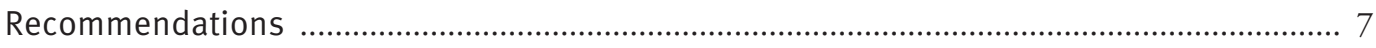

1. Context and rationale: globalization and diaspora communities .................................. 10

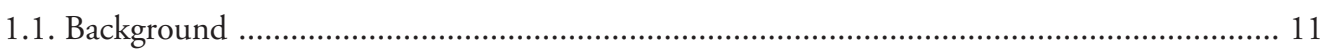

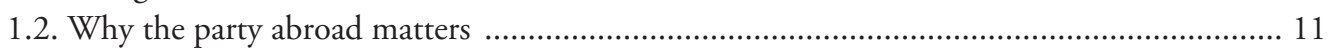

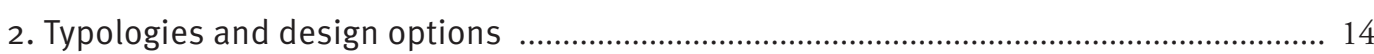

2.1. Objectives for establishing a party abroad: a typology ....................................................... 14

2.2. Organizational models of the party abroad: a typology ..................................................... 18

2.3. Legal frameworks of the party abroad ..................................................................... 20

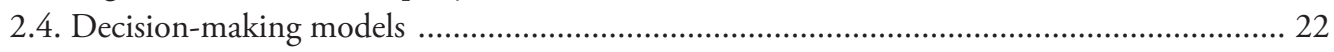

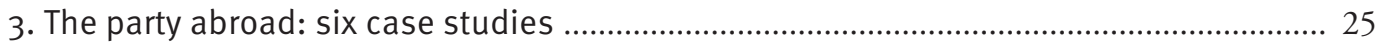

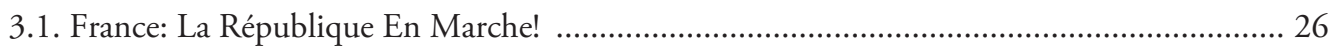

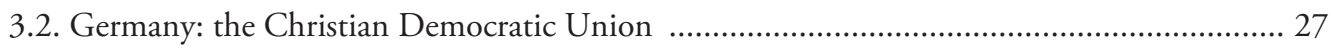

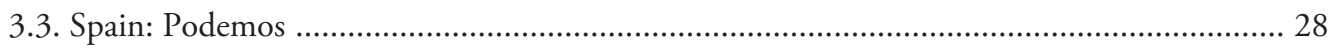

3.4. Turkey: Republican People's Party …………………................................................. 29

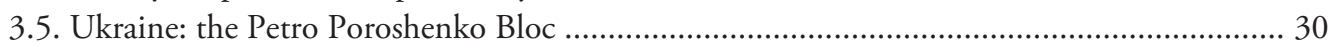

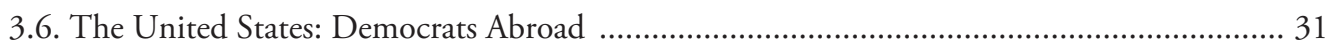

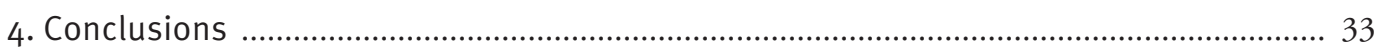

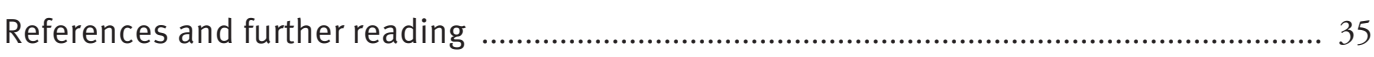

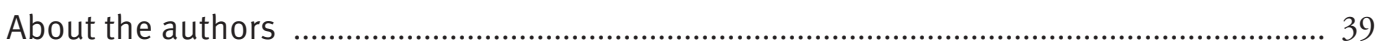

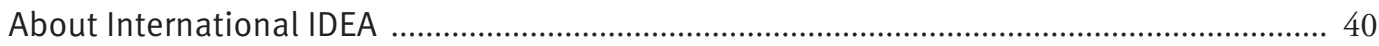




\section{Acknowledgements}

This paper was the outcome of a research fellowship by Ekaterina R. Rashkova at International IDEA, from February to April 2018. Research and interviews with political parties were conducted jointly with Sam van der Staak. Special thanks to each of the representatives of the political parties that were interviewed, Robbie Checkoway, Arthur Corbin, Virginia Dronova, Esperanza Jubera, Markus Lackamp, and Arzu Ozalp. Useful comments were provided by Adhy Aman, Lina Antara, Alberto Fernandez Gibaja, Lourdes González Prieto, Philipp Hansen, Miguel Ángel Lara Otaola, Therese Pearce-Laanela, Leena Rikkilä Tamang and Abdurashid Solijonov. Finally, warm thanks to Utrecht University for supporting Ekaterina Rashkova's contribution to policymaking in the important field of political representation. 


\section{Summary}

Within the ongoing discussion about immigration in Europe, increasing attention is being paid to the role of migrants' political representation within their host country or country of origin (Bekaj and Antara 2018). In various countries, the electoral behaviour of citizens who reside outside their nation of origin - the diaspora-has played a key role in the success of political parties.

The research presented in this Discussion Paper looks at the idea of the party abroad and aims to unravel how and to what extent national political parties engage with their citizens who reside outside their country. It considers the legal treatment (or non-treatment) of the operations of political parties beyond national borders and offers suggestions based on party rules existing in the national party law. It delineates the potential functions that diasporas may have for domestic politics and matches these with the potential goals of national political parties. As a result, the paper provides guidelines for practitioners on how to engage with their citizens residing abroad.

How can political parties engage the diaspora in the domestic political process? This paper focuses on presenting various models that can be used by political parties wishing to engage with their citizens abroad. Knowing what the party wants to achieve and how much time, effort and resources it is willing to invest in reaching that goal are essential prerequisites when making a decision about which model to use. Parties can apply the typology and extended research presented in the paper and, depending on the type of diaspora different national parties are facing, make an informed decision about which strategy is best for them.

The guidelines provided may prove beneficial to parties in both young and established democracies, especially those with many citizens residing abroad. This is illustrated by short case studies based on interviews with political parties in France, Germany, Spain, Turkey, Ukraine and the United States, which have either significant experience in the operation of political parties abroad (Germany, USA) or large diasporas (Turkey, Ukraine) or both (France, Spain). The results from these interviews serve as examples of what parties have done or hope to do in these countries and provide the basis for the paper's conclusion and recommendations. 


\section{Recommendations}

The potential for establishing the party abroad is large, given the high numbers of eligible voters in diasporas. Yet it is still in its infancy in terms of foreign chapter size and party institutionalization. This paper therefore offers the following recommendations for national governments, parties, and civil society and academia.

\section{For national governments}

1. Initiate discussions about the party abroad. In a context of rising migration on the one hand, and growing out-of-country voting and parties abroad on the other, public debate about migrants' political participation is likely to increase. Those governments with a clear view on the right of and limits to democratic participation in origin countries will be prepared to respond appropriately to instances of foreign campaigning or political activity by diasporas.

2. Take a holistic approach to political representation abroad. Discussions about the party abroad are intrinsically related to out-of-country voting, reserved diaspora seats in parliament, and the ability to transfer public funding abroad. All these instruments should be looked at as a whole to create a suitable framework for out-of-country political representation.

3. Regulate the operation of political parties abroad. This includes the three groups of laws that regulate: (a) registration of and campaigning by foreign parties; (b) out-of-country voting; and (c) funding of the party abroad.

4. Seek regulatory alignment between countries of origin and host countries. Some legislation sits with the host country (e.g. registration), while other laws must come from the country of origin (e.g. out-of-country voting, party funding). Ideally, both sides legislate with some level of alignment.

5. Encourage regulatory alignment and data exchange among municipal registries (at minimum within the EU) for the purpose of voter registration or dissemination of election notifications.

6. Invest in research on the party abroad. Despite many parties abroad being in their infancy, foreign chapters seem to develop rapidly. Governments have 
recently begun to regulate their behaviour, mostly in response to specific incidents. International comparative research creates in-depth understanding of the party abroad, and helps to build stronger regulatory frameworks.

\section{For political parties}

7. Invest in the party abroad. Political parties in countries with significant diasporas stand to benefit from greater activity abroad. As electoral participants they should look seriously at the potential of engaging with diasporas. As colegislators they should engage in debates over regulating the party abroad, and over related issues such as reserved diaspora seats in parliament and the organization of out-of-country voting. Parties can also invest in research on people living abroad, including on their socio-demographic profiles and their political awareness and engagement.

8. Take into consideration all five potential objectives when organizing the party abroad: social support and political education; network development and policy input; leadership recruitment; fundraising; and collecting votes. The potential of the party abroad is significant in some areas, and less so in others, and parties would benefit from taking into account existing practices.

9. Consider giving foreign chapters greater influence over the mother party. Instruments include internal voting rights, statutory board positions and, where possible, co-funding of their activities. Foreign chapters often focus more strongly on diaspora interests than does the central party. Their goals and organizational design should therefore be seen as more than an extension of those of the mother party.

10. Be mindful of international sensitivities. Recent cases have revealed the fragile environment for campaigning on foreign territory. Parties should therefore take utmost note of foreign sensitivities and be mindful of the legislation under which they are allowed to operate.

11. Make full use of online technologies to bridge the gap between the mother party and the party abroad. Digital technologies make it increasingly easy to participate in party affairs from a distance. Successful instruments include online policymaking, online candidate selection and online political crowdfunding. Any decision on any of the strategic goals to invest in the party abroad must be preceded by research as to whether voters abroad match target groups and therefore are worth investing in. 
For civil society and academia

12. Organize debate and conduct research on the role of the party abroad. Civil society and academia can help governments take sound regulatory decisions that go beyond stop-gapping incidents. More research and debate, however, are needed to deal with thorny issues such as regulation, cross-border oversight and ensuring a level playing field beyond borders.

13. Diaspora organizations and networks should make their knowledge of the diaspora population available to governments and political parties in order to shape a constructive and public debate about the party abroad. 


\section{Context and rationale: globalization and diaspora communities}

The democratic modus operandi is fully dependent on the conduct of free and fair elections in which political parties representing various ideological positions present their political agendas to voters who, in turn, have the ability to freely choose the course of the future political development of their country.

While elections are vital to the functioning of democracies around the world, with the ever-expanding effects of globalization-free trade and movement of workers, international treaties and cooperation, and dependency-there is a growing number of people residing outside their country of origin. In 2016, 3.1 per cent of the population of the European Union was born in another EU Member State (Eurostat 2017). The United Nations' International Migration Report 2017 stated that, in 2017, there were an estimated 258 million people residing in a country other than their country of birth, a 49 per cent increase since the 2000s (UN 2017).

While the reasons given by members of diaspora communities, including migrants, expatriates and also refugees, for leaving their country of origin may naturally differ, this data suggests a clear trend which poses a new societal problem: how can people who reside outside their country of origin exercise their right to vote and express their political views, be it in their country of origin or their host countries?

At the same time, voter turnout and party membership-two of the primary indicators of citizen involvement in the political process-have been in rapid decline (Klaukka et al. 2017: 102). This suggests a need for improved instruments of representation for both those who reside outside their country of origin, broadly termed diaspora communities, and for those who provide this function, the political parties.

This Discussion Paper aims to provide an initial solution to this growing societal issue by emphasizing the potential role of political parties beyond the borders of the countries in which they are based - in short, the 'party abroad'. 


\subsection{Background}

The operation of political parties abroad is not an entirely new phenomenon, both empirically and academically speaking. Democrats Abroad (DA), the official organization of the US Democratic Party, has been in operation since the 1960s and has committees in more than 42 countries throughout the world. Others-including Dutch, German and Swedish parties-have also been involved in major international efforts abroad, not only serving their own expatriates, but also, through their international foundations, assisting in the development of political parties in young democracies (Burnell and Gerrits 2010).

The manner in which parties operate domestically-specifically, the rules governing their everyday conduct-has also been a focus of scholarly attention in recent years. Research has been undertaken not only to establish what rules govern political parties and how these shape political behaviour (Biezen and Borz 2012; Casal Bertoa et al. 2015; Rashkova 2015), but also to critically examine the issue of the relation between the rules and the rule-makers, and the roles of political parties in both making and operating under these rules (Katz and Mair 1995).

Yet most existing studies on party-system development and party regulation limit themselves to the operation of political parties domestically. We know relatively little about whether and how political parties conduct their affairs beyond national borders, to what extent this varies between countries, and why. The operation of the party abroad thus remains unchartered territory. This paper looks at the party abroad and its potential in the light of political parties' needs and wants from an empirical point of view. In this regard, its recommendations are born out of practitioners' experience and academic knowledge of domestic party competition and its extension to operations abroad.

\subsection{Why the party abroad matters}

Political parties have been underestimating the potential of voters abroad, given their ever-rising numbers. Recent elections around the world have called attention to the role and power of the vote of those citizens. For example, consider the role of the Turkish diaspora in Germany and the Netherlands in the Turkish national elections, which recently sparked international debate (see e.g. Die Welt 2018; NOS 2018). Or consider the data from International IDEA's Voting from Abroad Database, which shows that some countries in Europe-Ireland, for example-do not allow foreignresiding nationals to vote in national elections. At the same time, data for 2018 from International IDEA's Voting from Abroad Database shows that 154 states worldwide have some provisions for voting from abroad, up from 115 in 2007 (International IDEA 2018). A significant wave of legalization of voting from abroad among European states can be seen after the 1970s (see Figure 1.1). 
Figure 1.1. Introduction of voting from abroad in European democracies

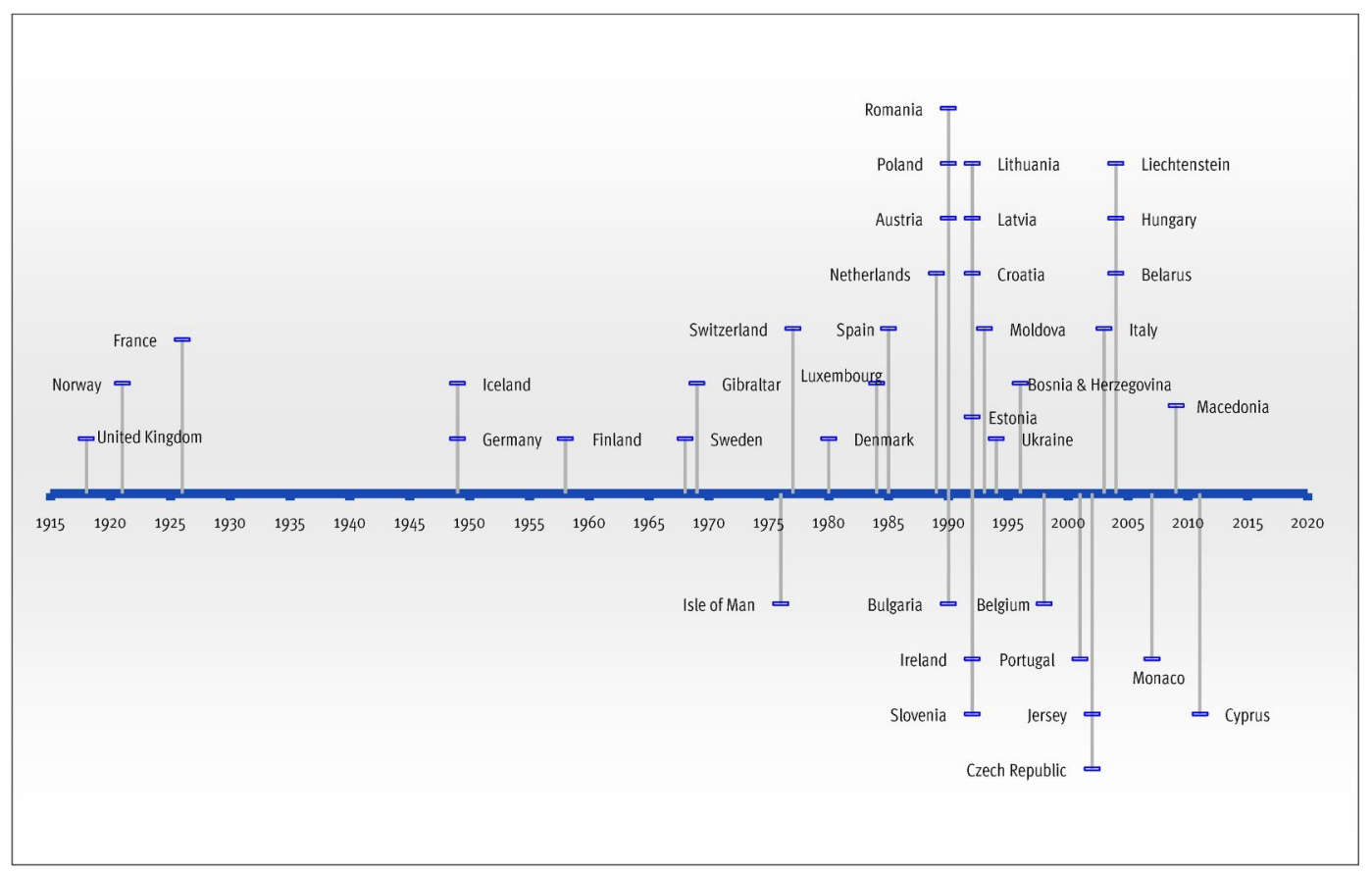

Source: International IDEA Voting from Abroad Database, <https://www.idea.int/data-tools/data/voting-abroad>.

Moreover, the scholarly debate on 'transnational voting rights' (Ellis et al. 2007; Caramani and Grotz 2015) and the notion of the 'party abroad' in general have started attracting interest. This is, after all, a topical issue. Most recently, French President Emmanuel Macron's proposal for transnational European Parliament lists - which was argued for as an attempt to make European Union institutions supranational rather than intergovernmental, and ultimately to offer a more direct link between citizens and political representative institutions in Brussels-was turned down by a slim majority (Hardy 2018). Finally, political parties from a number of established democracies have operated abroad under one form or another for an extended period of time.

The case for the potential of the party abroad can be further illustrated by data. One observable trend in international data is that of the movement of people around the world. Figure 1.2 depicts a number of European countries and their net migration flow over time. It illustrates that there are clear trends in countries that are receiving people (such as Germany and Italy) and countries that are losing people (such as Georgia, Moldova and Ukraine). Furthermore, statistics on the financial contributions of immigrants to their country of origin are telling. Figure 1.3 shows a positive trend of remittances being sent back to the country of origin: between 2.6 and 4.8 per cent. The figure shows further that two countries-Moldova and Georgia-have particularly high remittance rates, exceeding 10 and 25 per cent respectively.

These statistics suggest that, on the one hand, there are significant movements of people and a large number of people residing outside their country of origin and, on the other, there is a significant inflow of foreign-earned money sent by citizens to 
their countries of origin. The latter indicates a continued connection with the country of origin, and suggests a certain potential for parties seeking diasporas' political representation at home. Coupled with declining party membership and declining rates of voter turnout, this data suggests that there is a significant opportunity for increasing the political involvement of citizens living abroad.

Figure 1.2. Net migration of countries in Wider Europe

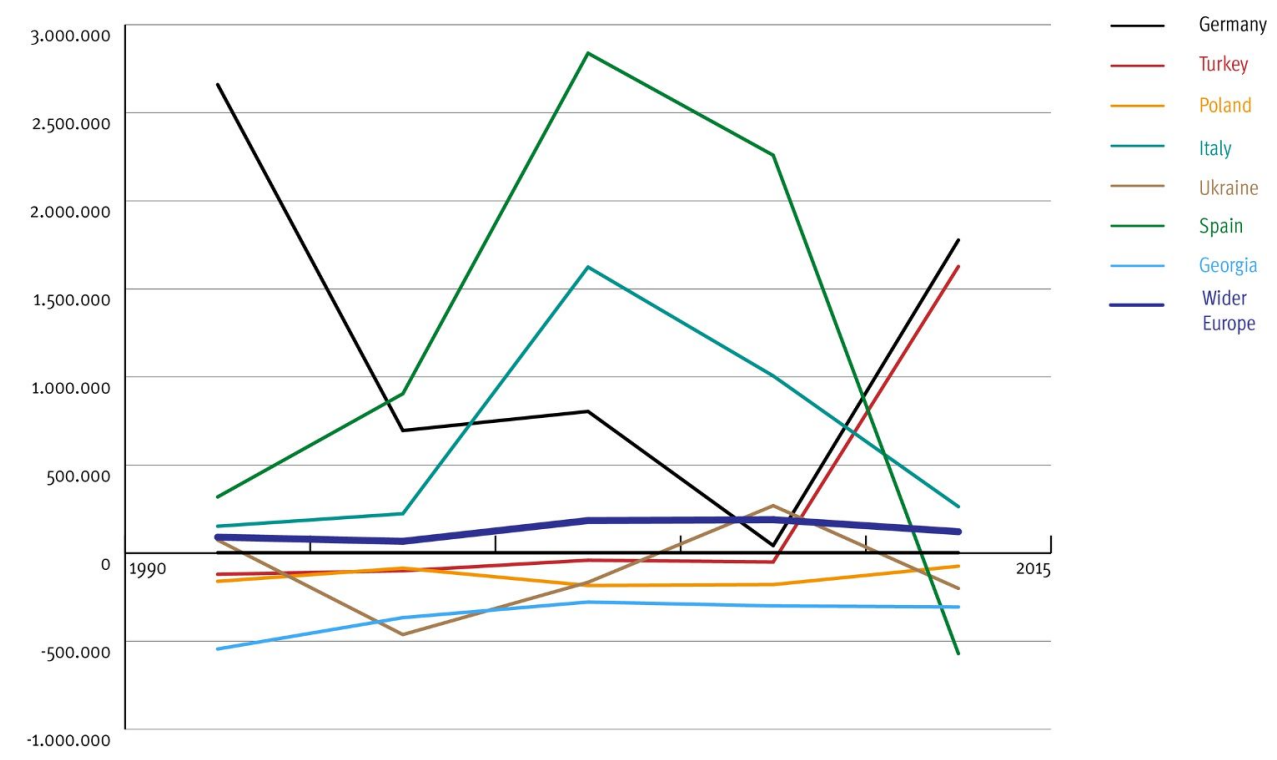

Source: US Federal Reserve Economic Data, <http://geofred.stlouisfed.org>

Note: Net migration data are available in comparative form only until 2012.

Figure 1.3. Remittances of countries in Wider Europe

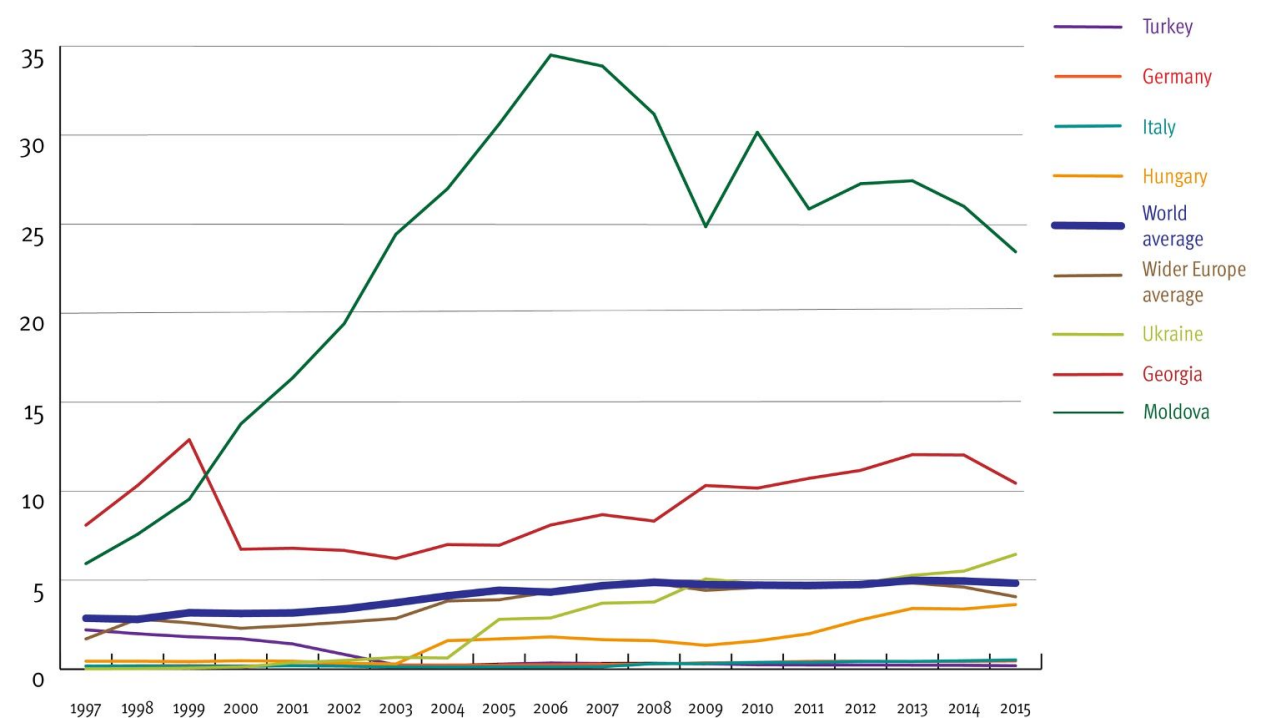

Source: US Federal Reserve Economic Data, <http://geofred.stlouisfed.org> 


\section{Typologies and design options}

A number of types of political party have developed over the last century-from cadre and mass parties (Duverger 1967) to the latest cartel (Katz and Mair 1995) and anti-establishment parties (Hino 2012). All of these omit one important feature of the 'life' of a political party-that is, its function abroad. This paper classifies the party abroad on the basis of extending Duverger's notion that a party is not a single community but a collection of communities, not restricted to but transcending national borders. The party abroad can thus be understood as any formal or informal establishment, function or activity of a national political party outside the borders of its country of origin.

\subsection{Objectives for establishing a party abroad: a typology}

An important consideration for any nationally active political party is whether and how to set up its operations abroad. This section presents a number of potential 'design options' that can be used by existing political parties wishing to explore the potential of party operations outside their borders. To choose an appropriate strategy, each political party will have to evaluate three constraints that define its functioning.

The first constraint that determines whether and how a national political party will choose to operate abroad is formed by its objectives. What are the goals and aims of the party? In addition, whose goals are being fulfilled? The latter will depend the type of relationship each party has with its members and local chapters (also known as local divisions).

The second constraint is the availability of resources. How much time and money can a political party allocate for its functions abroad? Overall, parties tend to know little about what kind of people have moved abroad or their exact whereabouts, since few register with the home country. Do those people represent potential target groups or are they likely to support rival parties or are they non-political? How politically engaged and aware are those citizens, before and after moving abroad? Social media increasingly allows for sophisticated targeting of these groups, which supports the notion of the growing importance of data and research for political parties.

The third constraint is the external layer of constraints imposed by the legal systems of both the country of origin and the host country. Is out-of-country voting 
allowed, and do diaspora-reserved seats in parliament exist? Are nationally existing political parties allowed to carry political functions abroad and, if so, under what conditions or rules? Moreover, are foreign political parties allowed to operate under the host country's legal framework and, if yes, are there any constraints?

This paper identifies five potential objectives for the establishment of a party abroad by any nationally active political party (see Figure 2.1): social support and political education; networking and policy input; recruiting candidates; fundraising; and voter mobilization. According to this typology, parties' objectives can be roughly allocated to three 'cost versus gain' categories, each with a different payoff and cost level:

1. Low cost, intangible/immaterial gain. This means that operating through the party abroad by adopting a strategy such as offering social support will not cost the national party much, but it will also not have a targeted payoff-there may or may not be one, but it cannot be easily predicted.

2. Medium cost, indirect gain. This involves more targeted behaviour. It has a specific goal but achieving it will require a certain degree of investment (both financial and logistical). Engaging in this category, then, indicates that national political parties are prepared to invest time and resources to pursue these objectives in the anticipation that they will receive indirect benefits in the future. Here, the potential benefits can be estimated, taking into consideration the type and extent of involvement abroad that the party plans.

3. High cost, direct gain. This refers to activities abroad that are well planned and carried out with a specific goal in mind-increasing the support for the political party (financially, as well as in terms of votes). This is the category in which political parties, if they engage, must be prepared to make the largest investment, but they also collect the largest potential benefit. The amount of gain can be anticipated to a large degree when basic statistics on the amount of investment and size of potential target group are taken into account.

This means that various activities and involvement can be planned and judged on the basis of the amount of effort they require (financial and non-financial efforts are all perceived here as 'costs') and the benefit that will result (different actions can lead to direct or indirect benefits: that is, something that can be easily seen and measured, such as financial contributions or people volunteering their time, or not so easily seen and measured, like a potentially favourable effect on a policy outcome, or finding a potential new candidate who may end up working for the party). 
Figure 2.1. Party-diaspora interaction scenarios

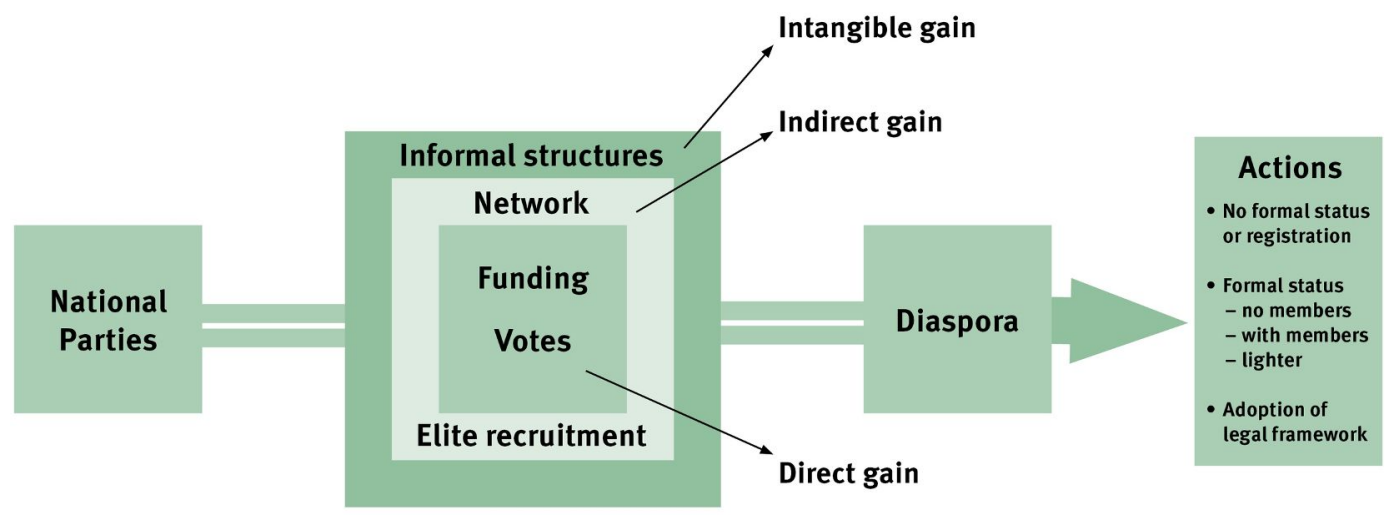

\section{Social support and political education}

Many foreign chapters explicitly define their goal as supporting diaspora communities. They engage diasporas in debates on what is happening at home. Sometimes foreign chapters also help their countrymen and-women face the challenges of living in a foreign country. This social function can include helping newcomers who do not speak the language of their new country, or who face social exclusion. Often, these are loosely created events without a fixed structure or systematic occurrence. This type of objective can be broadly termed 'low cost, intangible/immaterial gain'.

\section{Networking and policy input}

This objective relates to a targeted desire to expand a party's network outside the national borders, whether it is in a country with a large population of citizens of the country of origin (large diaspora), or a country with an important international decision and policy-making hub (such as Brussels for the EU). The goal of the party here is to broaden its network in order to serve its national interests either abroad or at home: opening doors for influencing foreign/international policy, getting party representatives in international positions, or collecting policy input for domestic decision-making. For instance, the Brussels chapter of La République En Marche! (LREM) sends information on the EU to the party in France to help it discuss EU issues at town level. Another type of input concerns policies that affect the diaspora itself, such as on out-of-country voting, or pension systems for diasporas. This type of objective can be broadly termed 'medium cost, indirect gain'.

\section{Recruiting candidates}

This objective relates to two current trends threatening the existence of political parties across the board-declining membership and lack of quality cadres (this is especially true for many new democracies, where a significant amount of highly educated and highly experienced citizens have left their country of origin to work and reside abroad). The purpose of a party with such an objective would be to expand or fill its candidate lists with highly qualified and internationally educated candidates, which can potentially help the party win more votes, but also get further ahead both 
nationally and internationally if it succeeds to be part of government. For instance, Estonia brought in ministers, ambassadors, and heads of institutions from the diaspora in the 1990s, in order to take advantage of talent, but also to break with the Soviet past. This type of objective can be broadly termed 'medium cost, indirect gain'.

\section{Fundraising}

This objective has to do with a political party wanting to generate additional funding either for its operations or for its electoral activities, or both. Given that party funding comes from both public and private sources (in most societies), and that the former is often linked to existing electoral success, generating one's own funds can give a significant advantage to political parties. Therefore, the goal of a party whose objective is to generate additional funds by operating abroad would be to activate the financial support of its citizens residing abroad, for example by pledging donations, support for a specific candidate's campaign, or another manner of indirect support such as offering premises, vehicles or support that could be used for party purposes. Ukraine's Petro Poroshenko Bloc (PPB) meets with diaspora leaders to encourage them to invest in Ukraine, and to establish businesses when they return to Ukraine. This type of objective can be broadly termed 'high cost, direct gain'.

\section{Voter mobilization}

This objective can also lead to 'direct gain'; it has to do with a party's goal to increase its electoral success by securing additional votes. Given that most European democracies operate under some sort of a proportional electoral system, where every additional vote counts and thus helps in the overall performance of a party, connecting the operations of the party abroad to voter mobilization is a an understandable objective. Political parties that are comparatively popular among expat communities have an extra incentive to mobilize diaspora votes through foreign chapters. For instance, the Spanish party Podemos claims it is the most voted-for party among Spaniards abroad, though it estimates that currently only 5 per cent of an estimated 2.5 million Spaniards abroad actually vote. This lends Podemos voter potential when engaging with the Spanish diaspora. Such an objective can broadly be termed 'high cost, direct gain'.

The typology of parties' objectives discussed above shows that they can be roughly allocated to three 'cost versus gain' categories, each with a different payoff and cost level. This means that various activities and involvement can be planned and judged on the basis of the amount of effort they require (financial and non-financial efforts are all perceived here as 'costs') and the benefit that will result (different actions can lead to direct or indirect benefits: that is, something that can be easily seen and measured, such as financial contributions or people volunteering their time, or not so easily seen and measured, like a potentially favourable effect on a policy outcome, or finding a potential new candidate who may end up working for the party). 


\subsection{Organizational models of the party abroad: a typology}

This section focuses on the types of organizational structures that the party abroad can take (see Figure 2.2). This is based on a number of criteria, including the extent to which the organization of the party abroad is (or is not) established based on formal rules and procedures, and the extent to which there is a link between the organization of the party abroad and the national party. With these broad divisions in mind, the following typology consists of three main types of party abroad organization: informal organizations, formal organizations with rights in relation to the national party body, and formal organizations without rights in relation to the national party body. Each of these types, as well as the manner in which their establishment and functioning is conceived, is described below.

Figure 2.2. Organizational models of the party abroad: a typology

\begin{tabular}{|c|c|c|c|}
\hline & & \multicolumn{2}{|l|}{ Level of organization } \\
\hline & & Low & High \\
\hline \multirow[t]{2}{*}{ Link to national party } & Weak & Informal party abroad & $\begin{array}{l}\text { Formal party abroad, } \\
\text { without rights at home }\end{array}$ \\
\hline & Strong & - & $\begin{array}{l}\text { Formal party abroad, } \\
\text { with rights at home }\end{array}$ \\
\hline
\end{tabular}

\section{The informal party abroad}

The organization of this type of party abroad is loose and most often not systematically structured. It therefore does not have formal premises, membership requirements, regular meetings or events; rather, it is run by volunteers, and events are planned when needed. Such a structure has low setting-up costs, is flexible and responsive to current needs and events, and usually involves a number of people devoted to the party's ideals and ideas who are willing to give up their time to render the service necessary.

The activities of such a party abroad include informal get-togethers, ad-hoc fundraisers, and the facilitation of electoral processes abroad, mainly through the supply of information. There may also be links with the national party when its members travel abroad: politicians may contact the party abroad on their own initiative, or be invited by it to attend an event during their visit. This type of organization can also serve to provide connections/contacts to citizens who may wish to establish a connection with politicians in their country of origin.

Examples of this type include the Christian Democratic Union's (CDU) Circles of Friends, which are set up around the world (see Chapter 3), or the Washington Chapter of the Dutch People's Party for Freedom and Democracy (Volkspartij voor Vrijheid en Democratie, VVD), which organizes occasional get-togethers for local Dutch expatriates. 


\section{The formal party abroad}

This type of party abroad organization can be divided into two subtypes, depending on the extent of the organization's influence and obligations.

\section{The formal party abroad without influence and obligations}

This subtype of a party abroad is formally registered and connected to the national party. As such, there is a structure to its organization and activities, responsibilities are allocated among volunteer or paid staff, and frequent contacts with the national party are established. This type of party, however, is not financed by or financially obliged to the national party. There is no formal party membership, or membership fees. Such an organization would have high setting-up costs but would still retain some of the flexibility and responsiveness of the informal party abroad organization. It has the potential to have a stronger influence on citizens living abroad and their connection to the domestic political process, due to its formal links with the national party organization.

This party structure does not have an official part in the national party's chosen political paths, nor does it have voting rights on internal party affairs. Examples of this type can be found in Turkey, where the foreign chapters do not have an official mandate in the party, but in reality meet regularly with the party at home, are taken into account when candidate lists are determined, and can nominate national board members.

\section{The formal party abroad with influence and obligations}

This type of party abroad is also formally registered and connected to the national party. The connection here is more complex than the one described above, due to the formalization of membership, the collection of membership fees, and the potential influence over the party's domestic policies. This organization has members and, depending on the national model (federal vs unitary), it may be required to pay all or part of the collected membership fees to the national party. It keeps close ties to the national party. It has the potential to influence national party politics by sending opinions and declarations, or in some cases by having its own delegate in the party's national structures.

An example here is the German CDU and its Brussels chapter, which has the right to send its own delegate to national party congresses. Also, LREM in France and Podemos in Spain have a dedicated diaspora representative on their national executive committees, in addition to the party's international secretary. Another example to consider is DA, which can send delegates to the gatherings of the national party. The party abroad can be financed with the help of the national party, or can be financed by itself, most often through membership fees. It may be obliged to pay a certain percentage of its membership fees to the national party (as, for example, CDU-Brussels does). The implications for this type of party abroad model are that it is a high-cost, direct gain model in which the organization has the resources and the potential to (formally) reach the diaspora community, to engage and help them take part in the national political process, as well as to, perhaps, influence the national party's direction of development. 


\section{Individual membership abroad}

Lastly, an emerging form of foreign activity that fits the model of formal rules with strong links is that of individual membership abroad. This form goes beyond the classic organization of chapters based in a particular country, and requires that political activity is mainly organized in the online space. Although still in its infancy in many places, such online engagement has the potential to serve as a model to reach out to people abroad directly regarding any of the five strategic objectives. One European-level party that has experimented with individual membership abroad is the Alliance for Liberal and Democrats for Europe (ALDE) Party, although it is different in that it is a European alliance of national parties so it lacks a 'mother party' in one particular home country.

\subsection{Legal frameworks of the party abroad}

Drawing upon insights from the Party Law in Modern Europe project, this section discusses the main points of legal consideration which political parties wishing to operate abroad may encounter. Given that the party abroad links both a nationally operating political party (whether the relationship is formal or informal) with the international political reality of a foreign (host) country, it needs to function within the legal boundaries of both the country of origin and the host country. Below, we discuss the main points of legal consideration which political parties wishing to operate abroad may encounter.

\section{Legal framework pertaining to the country of origin}

The first distinction to be made is between countries that regulate their political parties' foreign activity and those that do not. If a country chooses to regulate its political parties' functions abroad, there are a number of legal rules that may govern their conduct. These include eligibility and establishment rules, and organizational rules comprising membership rules, funding rules, rights and responsibilities in respect of the national party's rules, representation rules and function rules.

\section{Eligibility and establishment rules}

Eligibility and establishment rules pertain to the regulations describing the conditions under which national political parties can operate abroad. There is the potential for different scenarios: all nationally registered political parties may be free to operate outside the geographical borders of their country of origin, or that rule may be applied with a certain level of restriction (only political parties that stand for national and European elections; or only political parties that have received at least a certain percentage of the national vote; or only nationally represented political parties). An example can be found in the USA, where chapters of parties set up in individual countries but not registered with the Federal Electoral Commission are forbidden to campaign, and are only allowed to conduct 'get out the vote' campaigns.

\section{Organizational rules}

Organizational rules are any rules dealing with how the political party abroad can or must organize itself. There are two main types of organization that may be legislated 
in the law-formal and informal organizations. If political parties abroad have informal status (that is, they are not formally registered as a national party), the law will stipulate which aspects of regulation do not apply-such as membership requirements, membership dues, offices, regular meetings and outcomes, and so on. Alternatively, in order to function outside their national borders, political parties may be required to have a formal organization. This would in first instance require registration in the host country and/or the country of origin. Furthermore, the requirements for formal organizations can be split into two subtypes of party organization: one has a membership requirement as well as the right to influence the national party by, for example, sending representatives to its internal party congresses; the other has a formal structure without the requirement of membership, and without the right to influence the national political party. Another legal matter is the (public) funding of such party organizations abroad. Funding can be attached to membership numbers or vote numbers, or simply to the size of population (the diaspora) that such an organization is expected to serve.

Examples of organizational rules, and the extent to which they have been observed in countries that have parties already operating abroad, include the following:

1. Membership rules. These rules explain whether and to what extent the party abroad is obliged to seek formal members and collect fees from them.

2. Funding rules. These rules stipulate how the party abroad can fund itself. For instance, whereas French parties abroad can freely transfer rules on public funding to their foreign chapters, political parties in Spain and Turkey face legal obstacles to using public funding for activities outside the country. In the case of Moldova, the law prevents its citizens (both residents and nonresidents) from donating income obtained outside the country, although it should be noted that allowing or disallowing funding from the diaspora is a difficult issue, as it juxtaposes the right to democratic participation of diasporas with the threat of foreign interference.

3. Rights and responsibilities rules. These rules define the 'power relationship' between the party abroad and the national party. Rules in this category are related to the right to influence internal party democracy, party ideology and future political direction.

4. Representation rules. These rules state whether and to what extent the party abroad can participate in internal party matters, such as the national party congress or party committees.

5. Function rules. These are the rules that lay down the reasons for setting up a party abroad. They may be liberal and basically state that the function is to be determined by the leaders of the party abroad organization; or they may restrict the party abroad's functions to concrete tasks that serve the national party's interest, for example voter mobilization, fundraising, candidate supply and so on. 
Provisions such as those listed above can typically be included in national legislation that establishes the rules on the existence and operation of political parties. In most countries, this would mean the party law. The Serbian Party Law is one of the few party laws in Europe that makes reference to the activities of political parties abroad (Serbian Party Law 2009, articles 14, 23, 33 and 37) and legally allows membership and the formation of alliances abroad, as long as the goal is not the destabilization of the territorial entity of the Republic of Serbia. Most European party laws make use of the term 'abroad' in reference to allowing or disallowing funding from foreign entities. Alternatively, the issue of the party abroad may be addressed within individual party statutes, where political parties decide how to 'regulate' their own activity abroad. An example here is the German CDU with its single formal chapter in Brussels and its multiple Circle of Friends groups around the world.

\section{Legal framework pertaining to the host country}

As with the legal framework within the country of origin, the first distinction to be made is between host countries that regulate the activity of political parties from abroad and those that do not. If a country regulates political parties from abroad, there are a number of legal rules that may govern the parties' conduct in the host country. These include the right of establishment and operation, and rules about the type of operation.

\section{Right of establishment and operation}

These are rules from the host country about the establishment and operation of foreign political parties within its national boundaries. Such parties may be allowed, allowed with restrictions or not allowed. For example, Slovenian party law explicitly states that a party whose head office is registered abroad is not allowed to pursue its activities in the Republic of Slovenia (Slovenian Party Law 2007, article 3).

\section{Type of operation}

These rules relate to the type of operations foreign political parties are allowed to carry out in the host country. They can include, but are not limited to, regular meetings, vote mobilization and public campaigning, fundraising events and public speeches. In April 2018, Austria announced an amendment to its law on public gatherings, which would ban assemblies that serve the political activity of thirdcountry nationals or that harm Austria's interests. In May 2018, Turkish President Recep Tayyip Erdogan held an international election rally in Sarajevo, targeting the many Turkish voters residing abroad. This followed bans on political activity in Austria, Germany and the Netherlands, all of which have large Turkish minorities, a sizeable share of whom support the Justice and Development Party (AKP) (Balkaninsight 2018).

\subsection{Decision-making models}

National political parties which are considering whether and in what manner to operate abroad need to start their decision-making process by delineating their goals and objectives and by collecting information on the size and type of diasporas that 
exist. The latter will help them evaluate the potential impact that a diaspora community might have on the party, if they decide to engage with it, and can help to identify target countries.

When studying the diaspora, parties need to know three things: the size of the diaspora community, its level of homogeneity (age, education level, income) and its level of political engagement (both in the country of origin and the host country). The CDU, for example, finds that one of the biggest challenges when reaching out to its expatriates is their major differences in age, education, income and social status (heterogeneity); in addition, many German citizens who live abroad never register with their Embassy after moving to a new country. The result is a vast amount of potential supporters with whom the party has no contact.

Those countries in which political parties can have the highest impact if they engage with a party abroad are those with a large and relatively homogeneous diaspora. Medium impact can be achieved in countries with a small but homogeneous diaspora or a large and heterogeneous diaspora if the diaspora groups are politically active. The final category is a small heterogeneous diaspora, in which case, regardless of the level of its political activity, the recommendation is not to engage (Figure 2.3 summarizes these options).

Figure 2.3. Types of diaspora

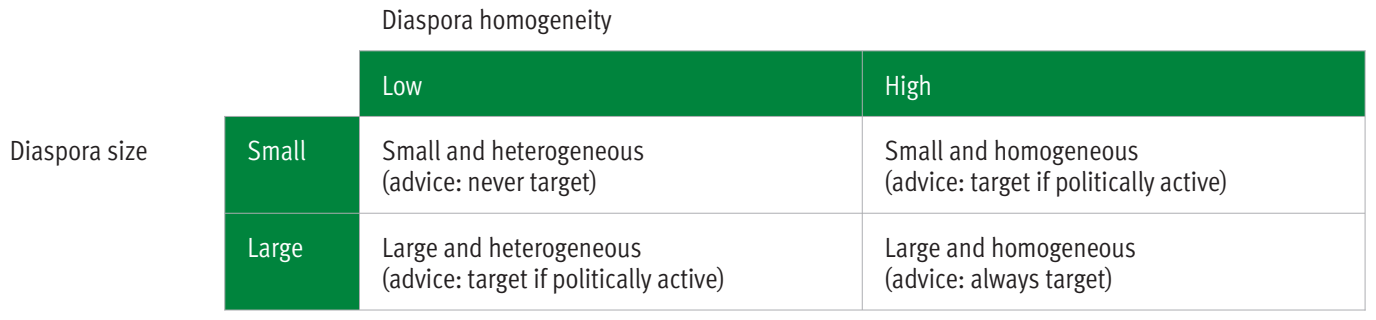

In order to make a decision and choose the strategy it wants to follow, a political party needs to consider its objectives and goals with regard to the type of diaspora it is facing. Figure 2.4 provides an illustration of potential strategies a party may choose to follow. The party should start at the top middle question of the decision-making tree and define its objectives: to support social and political education (informal network), to establish a network and gain policy input (build network), to recruit new elite members (elite recruitment), to raise funds (funding) and/or to collect votes (votes).

The next step is to locate the type of diaspora in the given country: small or large, heterogeneous or homogeneous. Parties' strategies will differ depending on their goal and the type of diaspora they are facing. A small and heterogenous group may need some additional orientation in the value of participating in politics abroad, while a large homogeneous group would be best suited for 'targeted campaigning'. A further consideration could be whether the diaspora group is politically active or inactive, as this may suggest something in relation to the effort political parties need to put in to achieve their predefined goal. Some political parties in France, Spain and Turkey, find politically inactive diasporas as a stimulus rather than a deterring factor. 
Figure 2.4. Decision-making tree for party actions

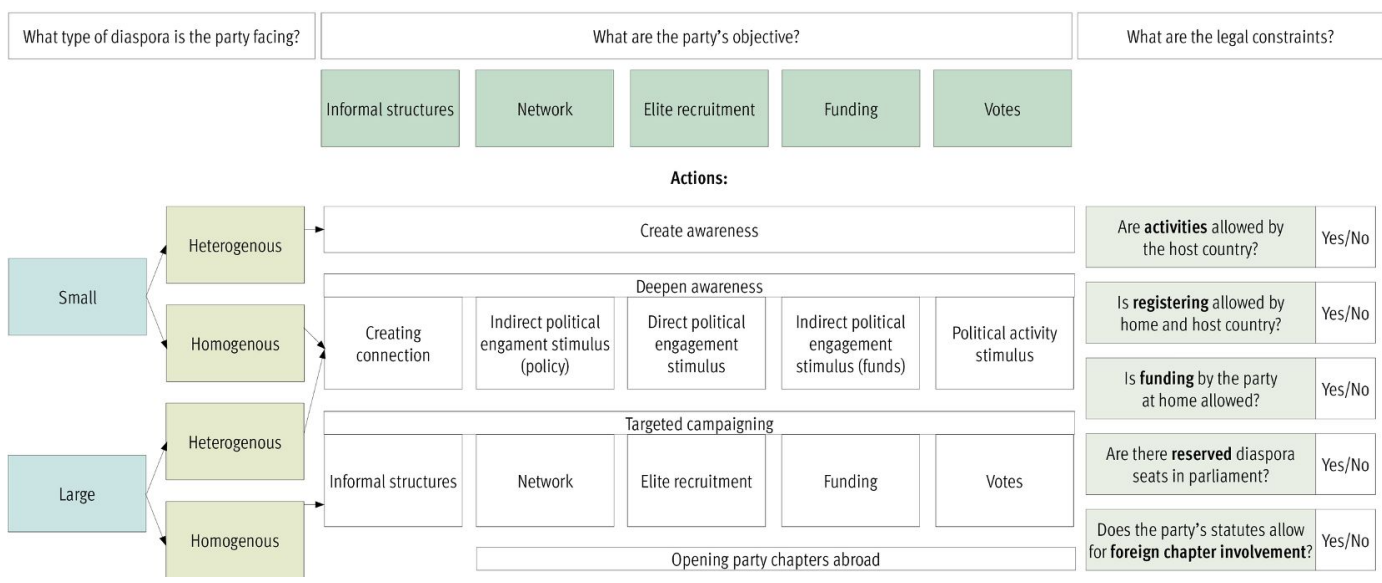

Based on the information gathered, parties can then follow the tree to the advised strategy. For example, a party whose goal is to recruit new leaders while faced with a small homogeneous diaspora needs to invest in directly stimulating political engagement by, say, holding a candidate recruitment day in the given country. If, alternatively, the main objective is to raise funds, the stimulus needs to emphasize the value of indirect engagement by showing what the contributed funds will help to achieve.

It should be emphasized that research and a data-driven approach are requirements for applying the decision-making tree. No matter how homogeneous or heterogeneous the diaspora is, without a knowledge of the target groups any effort is likely to be ineffective and a waste of money. With better targeting and better information about the added value of each group, the return on campaigning in small communities increases. 'Small' in these cases can actually make a big difference for a party in a low turnout election if it is able to run a 'get out the vote' operation in the diaspora. 


\section{The party abroad: six case studies}

A political party's decision on whether or not to operate abroad may be influenced by a number of contextual factors. These can be related to domestic characteristics, such as the electoral system, whether the country is unitary or federal and how this translates into its political operations abroad. For instance, France and Italy have reserved parliamentary seats for voters abroad, which makes foreign party activities and funding the party abroad much more common and accepted. The extent to which diasporas' socio-economic profiles match party policies also influences the decision to start abroad. A diaspora of mainly high-income expats is likely to sympathize more with some parties than others. Parties that are popular among youth may invest more in diasporas escaping mass youth unemployment.

Other contextual factors include the culture of 'connectedness', economic development, and the level of democracy and party system institutionalization in the home country. A young democracy with a high level of emigration and low level of party system institutionalization (that is, countries in which electorally successful political contestants change quickly over time) will have different goals and face different constraints in engaging with its diaspora, than will an established democracy with lower emigration levels and a high level of party system institutionalization.

Types of engagement may vary further depending on the different goals and motivations of political players at various levels - the central party, the local chapter, the chairperson of an informally organized group (an example is the local engagement of the Spanish party Podemos with its diaspora, described below). In order to construct a framework of analysis, which allows for comparisons between political parties and countries at a later stage, the model offered in this paper presents the decision-making scenarios from the viewpoint of the national political party.

To best address the link between theory and practice, political representatives from Germany, France, Spain, Turkey, Ukraine and the USA shared their party's experiences in engaging with their voters abroad. These six case studies were chosen to reflect a geographical spread, the ideological diversity of political parties, a mix of established and younger democracies, and countries with different types of diaspora. 


\subsection{France: La République En Marche!}

La République En Marche! (LREM) is a centrist political party with pro-European liberal views. It was founded by the current French President, Emmanuel Macron, in April 2016. In late 2018, it affiliated itself with the Alliance of Liberals and Democrats for Europe (ALDE), a European party family. Despite its newness, the party won France's 2017 presidential and parliamentary elections.

\section{How does LREM operate abroad?}

There are an estimated 2.5-2.6 million French citizens residing abroad, according to LREM. The party has 28,000 members in 110 countries. Its operations abroad are organized into 16 zones and 450 local committees (comités locaux). The Benelux is one of these 16 zones, comprising 33 local committees, of which Brussels is the biggest with 700 members. The Benelux zone supports the local committees in developing their bases. Activities organized by LREM range from internal workshops with members to external events such as breakfast meetings with Members of Parliament or Members of European Parliament, or marketing events to engage with citizens.

Members of LREM do not pay fees. Financial support comes from public funding and is provided by the national party to the LREM zones, and is then further distributed by the zone leader. The zones and committees of LREM abroad are largely independent, though the party's headquarters in Paris has a team that provides guidance to the zones, for instance on how to hold and organize rallies, as well as offering administrative and legal support.

Two members of the LREM executive committee are responsible for the French diaspora: one specifically deals with the foreign chapters; the other is the international affairs executive. The Benelux representative of the party has monthly calls with these members, which demonstrates a close connection between the national party and the party abroad.

\section{Why organize in such manner?}

The structure of the party abroad-with zones and committees-reflects the decentralized nature of LREM, as does the fact that LREM members do not have to be French. For example, the Brussels committee includes Belgian citizens. However, the issues that the party deals with are French issues.

France has 11 reserved seats in its National Assembly for French citizens abroad, including one for the Benelux. Whereas the elected representative for the Benelux represents French citizens in the Benelux broadly and regardless of party affiliation, the LREM abroad represents LREM members in the Benelux more directly.

\section{What are the main goals and legal arrangements in operating abroad?}

LREM abroad has at least four main objectives: (a) creating awareness among French citizens abroad about what LREM is doing for them; (b) promoting France's role in the world; (c) using the diaspora's input for policies at home (for instance, LREM Brussels sends information about the EU to help the party discuss EU issues in French villages); and (d) making French citizens abroad aware that they can vote. 
LREM abroad does not aim to open doors for France or French officials within institutions such the EU.

Although out-of-country voting is considered a relatively accessible procedure, certain barriers remain for French citizens wanting to vote from abroad. LREM therefore argues for the reintroduction of e-voting, which was also a policy proposal in Macron's 2017 election manifesto. Finally, LREM faces legal impediments in countries such as Luxembourg and Poland, where parties are not allowed to campaign or be registered. However, it does not fight these restrictions, and instead chooses to operate in a different setup or not at all (van der Staak 2018).

\subsection{Germany: the Christian Democratic Union}

The Christian Democratic Union (CDU) is a Christian Democratic, liberal conservative political party, founded in 1945. Its current leader, and Germany's Chancellor, is Angela Merkel. In 2016, its membership was recorded as 431,920 (Niedermayer 2017: 2).

\section{How does the CDU operate abroad?}

There is one formal party group abroad-CDU-Brussels — which has been created to represent CDU's pro-European stance in Brussels. CDU-Brussels is obliged to abide by the same rules as the national party, meaning that it has to collect membership fees, a portion of which goes back to the national party. CDU-Brussels does not receive direct financial support from the main party, since it is treated as a 'local level party', but occasionally receives indirect funding (e.g. in the form of stationery supplies). CDU-Brussels is characterized by a very high level of organization, which allows the national party to stay informed about who works there and who to contact.

CDU-Brussels has the right to (a) send one delegate to the 1,001 CDU delegates who meet regularly to discuss party matters (one place is always reserved for CDUBrussels regardless of how many members the party there has); (b) send drafts on various topics it deems important to the central party; and (c) send resolutions about specific actions to be taken to the central party.

Circle of Friends is another type of organization-one that has informal ties with the CDU. Circles of Friends exist in many places, but they are under no legal obligations; the people working closely with them or connected to them do not have to be members of the party; and the organization does not have to collect membership fees or pay dues to the national party. The connections between these organizations and the national party are less formalized; nevertheless, during federal and European Parliament elections the CDU sends them information about the election, the campaign, the candidates (including video interviews) and how to register and vote.

\section{Why organize in such manner?}

A major reason behind having only one formal party abroad organization relates to its legal obligations and to the inability of the national CDU to monitor the activities of organizations spread throughout the world. A further complication is the fact that 
Germans abroad are a heterogeneous group who may not have much in common apart from being German citizens.

\section{What are the main goals and legal arrangements in operating abroad?}

The main goal is to keep German citizens living abroad close to the party (voter mobilization), as well as to influence policy at the European level (EU policy).

The main legal obligation of CDU-Brussels is financial; it has to function in the same manner as other federal chapters, collecting membership fees and paying a portion of them into the national party. This is the principal reason why there is only one formal party abroad. Voting from abroad is relatively easy-the main legal obstacle is proving one's connection with Germany after residing outside the country for a period longer than six months (Rashkova 2018).

\subsection{Spain: Podemos}

Podemos is a Spanish left-wing political party which has been in operation since 2014. It quickly gained popularity with its anti-establishment stance and is the second largest party in Spain, at least in terms of the membership of its online portal, which currently stands at more than half a million people (Podemos 2018). Podemos has been relatively popular among young voters and Spaniards living abroad.

\section{How does Podemos operate abroad?}

Podemos has two types of structures abroad-circles and areas. The former, also called assemblies, are locally funded chapters and number about 30 globally. The latter are cross-country working groups that prepare policy solutions for diaspora interests, which are shared with the central party. Once a year the Podemos Abroad Forum takes place, funded by the central party. Podemos has 11,000 members abroad and believes it has strong potential among the 2.5 million Spaniards abroad, especially those who have fled youth unemployment. Podemos diaspora members have access to the central party via their representative. Furthermore, like all other members they can use an electronic application for e-voting called Agora Voting. They also may make financial donations to the party online.

\section{Why organize in such manner?}

Podemos strives towards a decentralized decision-making model that puts the emphasis on addressing diaspora concerns, and works towards 'local ownership of local problems'. Podemos believes that many of Spain's 2.5 million citizens living abroad sympathize with the party. However, only 5 per cent vote in national elections. Podemos claims that this is partly due to the difficult out-of-country voting process. Moreover, many Spaniards choose not to register with Spanish consulates when moving abroad as they stand to lose their healthcare insurance, thus barring them from voting from abroad. This has led the party to actively campaign for easier out-of-country voting procedures.

The central party pays for one salaried staff member who helps to coordinate the circles and areas, and elected representatives. Most people who are involved, however, do so on voluntary basis. When officials of the national party travel, they normally 
establish links with Podemos circles. Podemos circles meet online every three months, while the elected representative of Podemos abroad travels to Spain to meet other party officials four times a year.

\section{What are the main goals and legal arrangements in operating abroad?}

Podemos abroad's main goal is to serve the Spanish diaspora, and it tries to influence Spanish policymaking towards Spaniards abroad, while at the same time carrying out social mobilization and support functions for Spanish migrants (for example, providing language learning aids even to non-members). Another goal is to influence the Spanish government to open reserved parliamentary seats for voters abroad.

The main legal obstacles have to do with Spanish rules, which make the political participation of Spaniards abroad harder. In addition to the out-of-country voting procedures, there is a lack of clarity on the legality of using state funding from the central level to fund foreign chapters (van der Staak 2018).

\subsection{Turkey: Republican People’s Party}

The Republican People's Party (Cumhuriyet Halk Partisi, CHP) is the oldest political party in Turkey. It has a social democratic ideology and is currently the main opposition party. It is a member of the Socialist International and an associated member of the Party of the European Socialists.

\section{How does CHP operate abroad?}

More than three million Turkish voters are registered abroad. In Germany and the Netherlands alone, 1.4 million and 260,000 Turkish citizens respectively are entitled to vote. From the Turkish diaspora, 46 per cent, or 1.49 million people, voted in the 2018 presidential and parliamentary elections. Of these, 25.5 per cent voted for CHP's presidential candidate, and 18.2 per cent for CHP's parliamentary candidates (Reuters 2018). CHP's electoral potential abroad is therefore substantial.

CHP has (at least) 27 chapters outside Turkey, including in Australia, Canada, the EU and western Balkans. The chairpersons of the 27 foreign chapters meet with CHP Turkey regularly (more than twice a year) for two-day gatherings. In addition, chapters such as those for Belgium, Germany and the Netherlands meet regularly to organize joint activities and create common positions.

Members of foreign chapters pay a financial contribution, but are not necessarily members of the CHP party in Turkey, since there is no formal relationship between CHP abroad and CHP Turkey. Informally, however, the two organizations are linked. For example, two representatives of foreign chapters (in Berlin and the Netherlands) were placed on the party list of candidates for the 2018 national parliamentary elections. Furthermore, prior to that, the foreign CHP chapters had been invited to nominate a member for the board of CHP Turkey, a position that was ultimately taken up by the Strasbourg representative.

Why organize in such manner?

One of the reasons why CHP abroad organizes itself in a loose relationship with the mother party is its understanding that international law does not allow political 
parties to establish themselves outside their country of origin. This is why many CHP chapters exist as locally registered associations rather than as foreign branches of a political party.

\section{What are the main goals and legal arrangements in operating abroad?}

The main goals of CHP abroad are three-fold: first, represent the sizeable community of Turks abroad. Foreign chapter representatives consider themselves better informed about the interests and concerns of second- or third-generation Turks than those in Turkey. To keep up to date, foreign chapters organize regular activities, such as public debates between Turkish politicians and Turkey experts. Second, to help CHP delegations from Turkey with relevant access, for instance when CHP delegations travel and wish to meet political parties, civil society, companies or other stakeholders. CHP has strong ties with social democratic parties abroad, and facilitates contacts. Third, CHP aims to mobilize Turkish voters abroad, especially as it is of the opinion that among the Turkish voters who abstain, a majority is sympathetic to CHP. It mentions that other Turkish parties, which have larger funds and networks, invest heavily in voter mobilization.

There are considerable obstacles facing Turkish parties abroad. Some concern Turkish legislation, such as a ban on parties transferring funding abroad. CHP also strives for legislation that creates reserved diaspora seats in the Turkish parliament, a goal that is shared by the ruling AKP. Other legal obstacles concern host countries. The Austrian campaign ban on third-country nationals has already been mentioned. In Germany, it is illegal for foreign chapters to campaign three months before an election. And in the Netherlands, even though no ban on CHP activities exists, campaign events are sometimes prohibited for safety reasons. Lastly, foreign campaigning also makes it hard to monitor the existence of a level playing field. CHP refers to the dominant presence of the ruling AKP in many countries, and its access to available funding to transport its supporters to embassies in order to vote (van der Staak 2018).

\subsection{Ukraine: the Petro Poroshenko Bloc}

The Petro Poroshenko Bloc (PPB) is a centre-right, liberal conservative political party, established in 2014 around its leader, and Ukraine's current president, Petro Poroshenko. The party is pro-European and stands for Ukraine's westwards development in political and economic terms. The party had a recorded membership of 37,922 members in 2017 (Ukrinform.net 2017).

\section{How does the PPB operate abroad?}

The PPB currently does not operate abroad. Its leadership does, however, consider doing this in the near future, given the large number of Ukrainian citizens living abroad-over a million in neighbouring Poland alone (Puto 2017). Furthermore, according to Chmielewska et al. (2017), Ukrainian migrants in Poland work longer hours and transfer the majority of their earnings to their families in Ukraine-for 2015 , the estimated size of the remittances was $€ 1$.1billion. 


\section{Why organize in such manner?}

There are two main reasons for the lack of activity of the party abroad: low capacity and low priority. The first refers primarily to lack of funding and human capacity for foreign activity, and to some extent lack of active knowledge on how to do it. The second reason has to do with Ukraine's current political state-the PPB is a key player in strengthening the country and setting it on a path of political and economic recovery, so currently the party's priority is the domestic arena.

There is an active third/fourth generation Ukrainian diaspora in Canada and other parts of the world; they are connected to the party and support the democratic changes within their ancestral country. PPB keeps in touch with them and schedules meetings of the party's high-level officials when they travel internationally. The organization of such events is done via the Ukrainian embassies or via the leaders of the diaspora communities abroad.

\section{What are the main goals and legal arrangements in operating abroad?}

The two main goals for keeping ties with the Ukrainian diaspora are political influence and mobilizing foreign investment/setting up businesses by diasporas in Ukraine.

Most of the systemic obstacles are lack of resources to organize out-of-country voting, following budgetary cuts for embassies, and lack of information-in particular about how the first-generation Ukrainian diaspora is organized in various places (van der Staak 2018).

\subsection{The United States: Democrats Abroad}

Democrats Abroad (DA) is the organization of the Democratic Party for Americans living abroad. Founded in 1828, the Democratic Party is one of the two main parties in US politics.

\section{How does the DA operate abroad?}

It has the same status vis-à-vis the national party as each of the US states. As a result, it has eight seats on the Democratic National Committee (DNC) which meets twice a year and decides on internal and external matters. The party has members in 190 countries and 43 country committees. It is financed through donations only from American citizens.

\section{Why organize in such a manner?}

The party is highly organized and represents the 9 million Americans living abroad (6.7 million of whom are of legal voting age). Its status as a 'state' gives the DA an equal seat at the negotiating table in Washington, DC. It is concerned primarily with raising visibility and awareness of the issues faced by Americans abroad. Its decentralized manner reflects the American spirit of locally self-organized groups, while at the same time working towards a common goal of furthering Democratic representation in Congress. Fundraising takes place through events, appeals and auctions of donated items (such as 'a week in my vacation home in Spain'). The DNC provides indirect help, such as supplying office space and staffing. 
The volunteers working for the DA try to establish a culture in which American politicians travelling abroad will contact the local DA chapter whenever possible.

\section{What are the main goals and legal arrangements in operating abroad?}

Members of Democrats Abroad have a number of goals related to helping their party win domestically, but they also aim to influence policy to help their co-nationals abroad. First, a primary goal during elections is to stimulate the sending to the USA of as many ballots as possible in order to support the party and boost its chances of electoral success. This is necessary because voting from abroad is the individual's responsibility and many states use regular post, which deters citizens from voting as they find the process cumbersome.

A second goal of the DA is to have influence within the party. Such influence is stronger when the number of votes from abroad can tip the balance of an election. For example, in $2008 \mathrm{Al}$ Franken (a former senator from Minnesota) was elected on a very 'close' vote, with a few hundred votes making the difference; at that particular time the foreign vote was 3,000 , so the DA was able to argue that its votes matter. A third goal is to create visibility and awareness (reminding politicians in the USA about the 9 million Americans living abroad and their issues). Finally, the DA aims to influence policy. It works for its constituents and tries to resolve the many, often legal, issues for American citizens living abroad. Examples include the Foreign Account Tax Compliance Act; and medical insurance (Obamacare) in cases where US citizens who do not have US insurance risk being fined. In such cases, the DA lobbies for legal exemptions.

The most notable obstacle to the DA's operations abroad is that, under US election laws, it is not allowed to accept money in the form of a donation from anyone who is not an American citizen or a green-card holder. Furthermore, how local chapters keep track of their funds is cumbersome, as they have to keep local and international funds separately. As a non-registered body with the Federal Election Commission, individual country chapters are limited to advertising in local magazines. They can only raise awareness and promote voting; they cannot promote a candidate. In addition, they choose to stay out of the politics of the host country.

Voting from abroad can sometimes be a complicated process, depending on where a voter is registered. The DA organization has created a website (<https:// www.votefromabroad.org/>), which started operating in 2004, to serve Americans abroad and help them in all questions related to voting from abroad (Rashkova 2018). 
The case studies included in this Discussion Paper illustrate a variety of party chapters abroad. After looking into political parties from various ideological backgrounds, from both established and emerging democracies, and from various geographic regions, what is clear is that these parties see significant potential in the operations of the party abroad. Regardless of their different backgrounds and different agendas, all the political representatives interviewed attested to the large number of eligible voters outside the borders of their respective countries.

Another dominant finding is the emphasis placed by foreign chapters on serving and supporting their citizens abroad, rather than emphasizing the benefits to the central party. This is especially the case for the parties interviewed from France, Spain, Turkey and to an extent Germany, although the emphasis in the latter was more on keeping the diaspora close to the party. We saw an interesting alternative in Ukraine, where the diaspora is perceived as a group that can potentially help to advance the country both politically and economically. Most parties also wanted to establish reserved seats for the diaspora in national legislatures; this is something which exists in France already, but is still an aspiration in most other countries.

There seem to be two dominant structures in the parties abroad. Some have a more centralized organization, with formal status and powers within the party at home, such as CDU-Brussels. The other structure involves more local organizations, many of which do not have formal status or powers within the central party. They are nevertheless well connected to the core, such as the CDU's Circles of Friends or LREM's committees. What also stands out from the case studies is that all these organizations, regardless of their formal status, try to keep in touch with the national organization and politicians. Yet the central party and the foreign chapters may place different emphases on the goals of the party abroad. Foreign chapters often focus strongly on diaspora interests rather than on central-party or home-country issues.

A significant difference among the interviewed parties is their funding model. Some, such as the LREM's zones, are funded through national public funding. Others, such as the Turkish CHP, fund themselves through membership fees and do not pay any of these contributions to the national party. Still others, such as CDUBrussels, collect membership fees but members are also members of the national party, so a portion of the money is handed over. Parties such as the DA are also fully 
dependent on organizing their own funding. What stands out is that a majority of the parties currently operating abroad are self-funded.

Lastly, all party representatives interviewed mentioned the existence of significant legal obstacles which differ in each case but include obstacles to voting from abroad; to dedicated representation of diasporas in parliament; to registering and campaigning abroad; and to receiving funding from the central party. 


\section{References and further reading}

Balkaninsight, 'Turkey's Erdogan to stage election rally in Sarajevo', 25 April 2018, <http://www.balkaninsight.com/en/article/turkey-s-erdogan-to-organiseelection-rally-in-sarajevo-04-25-2018>, accessed 1 April 2018

Bekaj, A. and Antara, L., Political Participation of Refugees: Bridging the Gaps (Stockholm: International IDEA, 2018), <https://www.idea.int/publications/ catalogue/political-participation-refugees-bridging-gaps?lang=en>, accessed 19 November 2018

Biezen, I. van and Borz, G., 'Models of party democracy: patterns of party regulation in post-war European constitutions', European Political Science Review, 4/3 (2012), pp. 327-59, <https://doi.org/10.1017/S1755773911000294>

Burnell, P. and Gerrits, A., 'Promoting party politics in emerging democracies', Democratization, 17/6 (2010), pp. 1065-84, <https://doi.org/ $10.1080 / 13510347.2010 .520548>$

Caramani, D. and Grotz, F., 'Beyond citizenship and residence? Exploring the extension of voting rights in the age of globalization', Democratization, 22/5 (2015), pp. 799-819, <https://doi.org/10.1080/13510347.2014.981668>

Casal Bértoa, F., Piccio, D.R. and Rashkova, E., 'Party law in comparative perspective: evidence and implications', in I. van Biezen and H. M. ten Napel (eds), Political Parties and Public Law: the Netherlands in Comparative Perspective (Leiden: Leiden University Press, 2015)

Chmielewska, I., Dobroczek, G. and Puzynkiewicz, J., 'A new wave of Ukrainian migration to Poland', Central European Financial Observer, 19 January 2017, $<$ https://financialobserver.eu/poland/a-new-wave-of-ukrainian-migration-topoland/>, accessed 19 November 2018

Duverger, M., Political Parties: Their Organization and Activity in the Modern State (London: Methuen, 1967) 
Ellis, A. et al., Voting from Abroad: The International IDEA Handbook (Stockholm: International Institute for Democracy and Electoral Assistance, 2007), <https:// www.idea.int/publications/catalogue/voting-abroad-international-ideahandbook?lang=en>, accessed 19 November 2018

Eurostat, 'People in the EU: Statistics on origin of residents', 2017, <https:// ec.europa.eu/eurostat/statistics-explained/index.php?title=People_in_the_EU__statistics_on_origin_of_residents\#Foreignborn_residents_from_another_EU_Member_State>, accessed 22 November 2018

Hardy, C., 'EU parliament rejects transnational lists', Euronews, 7 February 2018, $<$ https:/www.euronews.com/2018/02/07/eu-parliament-rejects-transnationallists $>$, accessed 28 November 2018

Hino, A., New Challenger Parties in Western Europe (London: Routledge, 2012), <https://doi.org/10.4324/9780203130698>

International Institute for Democracy and Electoral Assistance (International IDEA), Voting from Abroad Database, <https://www.idea.int/data-tools/data/votingabroad>, accessed 1 August 2018

Katz, R. S. and Mair, P., 'Changing models of party organization and party democracy: the emergence of the cartel party', Party Politics, $1 / 1$ (1995), pp. 5-28, <https://doi.org/10.1177/1354068895001001001>

Klaukka, G., van der Staak, S. and Valladares, J., 'The changing nature of political parties and representation', in International IDEA, The Global State of Democracy: Exploring Democracy's Resilience (Stockholm: International IDEA, 2017), pp. 98-118, <https:/www.idea.int/gsod/>, accessed 11 June 2018

Nederlandse Omroep Stichting (NOS), 'Erdogan roept Turkse Nederlanders in brief op te gaan stemmen' [Erdogan letter calls on Turkish Dutch to vote], 14 June 2018, <https://nos.nl/artikel/2236543-erdogan-roept-turkse-nederlanders-inbrief-op-te-gaan-stemmen.html>, accessed 28 November 2018

Niedermayer, O., 'Parteimitglieder in Deutschland: Version 2017 NEU' [Party members in Germany: 2017 version, new], Frei Universitat Berlin, 2017, <https://www.polsoz.fu-berlin.de/polwiss/forschung/systeme/empsoz/team/ ehemailige/Publikationen/schriften/Arbeitshefte/P-PMIT17-NEU.pdf >, accessed 19 November 2018

Party Law in Modern Europe, The Legal Regulation of Political Parties in Post-War Europe, <http://www.partylaw.leidenuniv.nl/>, accessed 13 February 2019

Podemos, 'Portal de Participación de Podemos' [Podemos Participation Portal], [n.d.], <https://participa.podemos.info/es>, accessed 1 June 2018 
Puto, K., 'Second-hand Europe: Ukrainian immigrants in Poland', 2017, openDemocracy, 31 May 2017, <https://www.opendemocracy.net/od-russia/ kaja-puto/second-hand-europe-ukrainian-immigrants-in-poland>, accessed 19 November 2018

Rashkova, E. R., Electoral Law and Party System Development in Contemporary Central and Eastern Europe Database, 2015, <http://www.electorallaw.org>, accessed 19 November 2018

Ukrinform, 'The membership of the Petro Poroshenko Bloc "Solidarity" has grown by $34 \%$ in 2017', 8 February 2018, <https://www.ukrinform.net/rubricpolytics/2398730-petro-poroshenko-blocs-membership-grew-by-one-thirdin-2017.html>, accessed 19 November 2018

United Nations, Department of Economic and Social Affairs, International Migration Report 2017: Highlights (New York: UN, 2017), <http://www.un.org/en/ development/desa/population/migration/publications/migrationreport/docs/ MigrationReport2017_Highlights.pdf>, accessed 19 November 2018

Die Welt, 'Pflicht türkischer Politiker, in Deutschland aufzutreten' [Duty of Turkish politicians to perform in Germany], 22 May 2018, <https://www.welt.de/print/ die_welt/politik/article176566276/Pflicht-tuerkischer-Politiker-in-Deutschlandaufzutreten.html>, accessed 28 November 2018

Further reading

Potter, J. and Tavits, M., 'The impact of campaign finance law on party competition', British Journal of Political Science, 45/1 (2015), pp. 73-95 (first published online, 2013)

Rashkova, E. R. and Yen-Pin, S., 'Determinants of party system size: The effect of public funding in new and established European democracies', Paper presented at the Council for European Studies Annual Conference, Glasgow, 12-14 July 2017

Sartori, G., Parties and Party Systems (Cambridge: Cambridge University Press, 1976)

Scarrow, S., 'Party subsidies and the freezing of party competition', West European Politics, 29/4 (2006), pp. 619-39, <https://doi.org/ $10.1080 / 01402380600842148>$

World Bank, Population Database, 2017, <data.worldbank.org/indicator/ SM.POP.REFG>

Østergaard-Nielsen, E. and Ciornei, I., 'Political parties and the transnational mobilization of the emigrant vote', Working paper prepared for the conference of the Midwest Political Science Association, 2013 
Interviews

Rashkova, E. R., Interview with Christian Democratic Union representative, The Hague, March 2018

—, Interview with Democrats Abroad representative, The Hague, April 2018

van der Staak, S., Interview with Petro Poroshenko Bloc representative, The Hague, April 2018

—, Interview with Podemos representative, The Hague, April 2018

—, Interview with Republican People’s Party representative, The Hague, May 2018

—, Interview with La République En Marche! representative, The Hague, May 2018 


\section{About the authors}

Ekaterina R. Rashkova is an Assistant Professor at the Utrecht University School of Governance. Her research interests lie in electoral and party systems and the strategic behaviour of political actors. She works on the effect of institutions on party system development, party regulation and gender representation. Her work compares new and established democracies and has appeared in Comparative European Politics, International Political Science Review, Party Politics, Political Studies, Representation, West European Politics, as well as in several edited book volumes. She is an editor of European Political Science.

Sam van der Staak is the Head of International IDEA's Europe Programme, in which position he advises political parties, electoral commissions and other state institutions on a broad range of democratic reforms. He is the author of publications on topics including political party development, citizen movements, and political finance, and he is a regular commentator for various European media. Prior to his involvement in democracy assistance, he worked in the Netherlands House of Representatives. 


\section{About International IDEA}

The International Institute for Democracy and Electoral Assistance (International IDEA) is an intergovernmental organization with the mission to advance democracy worldwide, as a universal human aspiration and enabler of sustainable development. We do this by supporting the building, strengthening and safeguarding of democratic political institutions and processes at all levels. Our vision is a world in which democratic processes, actors and institutions are inclusive and accountable and deliver sustainable development to all.

\section{What do we do?}

In our work we focus on three main impact areas: electoral processes; constitutionbuilding processes; and political participation and representation. The themes of gender and inclusion, conflict sensitivity and sustainable development are mainstreamed across all our areas of work.

International IDEA provides analyses of global and regional democratic trends; produces comparative knowledge of good international democratic practices; offers technical assistance and capacity-building on democratic reform to actors engaged in democratic processes; and convenes dialogue on issues relevant to the public debate on democracy and democracy building.

\section{Where do we work?}

Our headquarters is located in Stockholm, and we have regional and country offices in Africa, the Asia-Pacific, Europe and Latin America and the Caribbean. International IDEA is a Permanent Observer to the United Nations and is accredited to European Union institutions.

<http://idea.int> 
In various countries, the electoral behaviour of citizens who reside outside their nation of origin-the diaspora-has played a key role in the success of political parties in their home countries.

The research presented in this Discussion Paper looks at the idea of the party abroad and aims to explain how and to what extent national political parties engage with their citizens who reside outside their country. It considers the legal treatment (or non-treatment) of the operations of political parties beyond national borders and presents various models that can be used by parties wishing to engage with their citizens abroad. 